This is the author's final, peer-reviewed manuscript as accepted for publication. The publisher-formatted version may be available through the publisher's web site or your institution's library.

\title{
An Alternative for Whom? Rethinking Alternative Education to Break the Cycle of Educational Inequality and Inequity
}

Jeong-Hee Kim, Department of Curriculum and Instruction, Kansas State University, ihkim@ksu.edu

Kay Ann Taylor, Department of Curriculum and Instruction, Kansas State University, ktaylor@ksu.edu

\section{How to cite this manuscript}

If you make reference to this version of the manuscript, use the following information:

Kim, J.H. \& Taylor, K.A. (2008). An Alternative for Whom? Rethinking Alternative Education to Break the Cycle of Educational Inequality and Inequity. Retrieved from http://krex.ksu.edu

\section{Published Version Information}

Citation: Kim, J. H. \& Taylor, K. A. (2008). An alternative for whom: Rethinking alternative education to break the cycle of educational inequality. The Journal of Educational Research, 101 (4), 207-219.

Copyright: Copyright @ Taylor \& Francis Group, LLC

Digital Object Identifier (DOI): DOI: 10.3200/JOER.101.4.207-219

Publisher's Link: http://www.informaworld.com/openurl?genre=article\&issn=00220671\&volume $=101 \&$ issue $=4 \&$ spage $=207$ 
RUNNING HEAD: An Alternative for Whom?

An Alternative for Whom?

Rethinking Alternative Education to Break the Cycle of

Educational Inequality and Inequity

\author{
Jeong-Hee Kim \\ Kansas State University \\ Kay Ann Taylor \\ Kansas State University
}




\begin{abstract}
It seems that the growing number of alternative schools correlates to the growing population of disenfranchised students. The more disenfranchised students there are, the more alternative schools are being built. This correlation may be due to social, economic, and political issues that cause pervasive social injustice, which reinforces the cycle of educational inequality. The purpose of this qualitative study is to examine one alternative high school from a critical perspective to determine whether or not the school is beneficial to the students to the extent that it works to break the cycle of educational inequality. Employing critical theory as a theoretical framework, we find that the school is successful in providing a caring environment for the students and gaining trust from the students. However, the school fails to offer a meaningful and equitable alternative education that benefits the students. This failure leads us to question for whom this school is truly an alternative.
\end{abstract}




\section{An Alternative for Whom? \\ Rethinking Alternative Education to Break the Cycle of Educational Inequality and Inequity}

\section{Introduction}

Alternative schools were prolific in the late 1960s and the 1970s across the United States. As the Civil Rights movement gained momentum, educational priorities shifted back to the progressive education movement by people who were dissatisfied with the traditional curriculum (Conley, 2002; Goodman, 1999; Raywid, 1995; Young, 1990). Alternative schools were opened to offer students opportunities for success based on the belief that one unified curriculum is not sufficient for all. They emphasized the development of self-concept, problem-solving, and humanistic approaches (Conley, 2002). Chapter 1, now known as Title I of the Elementary and Secondary Education Act of 1965, was a great support for alternative education. Its program funding was designed to prevent students from dropping out and academic failure (Land \& Legters, 2002). The development of alternative education was based on the idea that some students may learn better in an environment structured differently from that of traditional, academic public schools. Unfortunately, many alternative schools in this era did not last long due to structural mismanagement or mismanagement of school finance, which made it difficult for them to endure the growing public pressure for school accountability (Marsh \& Willis, 2003).

The popularity of alternative education regained its momentum in the mid 1990s in the form of public and private voucher programs, charter schools, or magnet programs, in an effort to satisfy the need for choice and diversity (Conley, 2002). According to the first national study of public alternative schools and programs serving at-risk students conducted by the National Center for Educational Statistics (NCES) (2001), there were 10,900 public alternative schools and programs for at-risk students serving approximately 612,900 students in the nation during 
the 2000-01 school year. Thus, 39\% of all school districts nationwide offer alternative schools or programs, and this number is growing every year. The study also found that alternative schools are located disproportionately in urban districts, districts with high minority student populations, and districts with high poverty concentrations, thus making them susceptible to social, political, economic and educational inequalities (National Center for Educational Statistics, 2001). Some of these alternative schools have been successful by satisfying "the need to provide choice and diversity within a monopolistic bureaucratic giant of public education" (Conley, 2002, p. 177). For instance, alternative schools in Washington State have been successful as an alternative to traditional public education, with schools effectively meeting students' different needs (see Billings, 1995).

However, public alternative schools today run by school districts still struggle with negative stigmas that perceive them as a dumping ground, warehouse, or for at-risk students who are falling behind, who have behavioral problems, or who are juvenile delinquents. These stigmas are some of the biggest obstacles for the success of alternative education (Arnove \& Strout, 1980; Conrath, 2001; Dryfoos, 1997; Kelly, 1993; Kim, 2006; Mcgee, 2001; Waxman, 1992). These negative stigmas have a tacit assumption that students' educational failure largely was caused by individual factors such as poverty, minority status, or family characteristics, and ignore external factors such as school condition and societal factors. This is a deficit-thinking paradigm that blames low socio-economic strata students for their failure in school. In this paradigm, systemic factors are ignored, i.e., school tracking, inequalities in school financing, curriculum differentiation, and low teacher quality—all of which function to maintain the status quo - nor are they held accountable in explaining why some students fail in school (Valencia, 
1997). As a result, students are blamed for their failures and they are viewed as burdens (Valencia \& Solorzano, 1997).

The purpose of this qualitative case study is to examine an alternative school from a critical theory perspective. Our research question is: In what ways is the school curriculum beneficial, or not beneficial, to the students in terms of equity? One concern central to critical theory is who benefits from education. With this in mind, we explore whether or not the school $\operatorname{program}^{1}$ is, in fact, beneficial to the students to the extent that it provides a level playing field, while breaking the cycle of educational inequality. Our understanding of "beneficial" comes from the perspective of critical theorists that schools in general work to benefit the elite upperclass people in the preservation of their existing social privilege, interests, and knowledge at the expense of less powerful groups. Therefore, a school program that helps disenfranchised students to succeed can be considered beneficial (See Anyon, 1997; Apple, 2004; Freire, 1997; Giroux, 2001). Specifically, we consider that a school program is beneficial to the students when it provides them with the content, processes, rigor, and concepts that they need so as to realize their future career goals. In addition, a school program that is beneficial to the students engages them and leads them through varying processes to critical thinking and synthesis of the concepts and content. Conversely, a school program that is not beneficial to the students by our definition is one that is behavioristic, positivistic and reductive. That is, its focus is primarily on an either/or dichotomy, it addresses only lower order thinking and processing skills, and it does not move students toward their future career goals. Further, a school program that is not beneficial to the students represents social reproduction, social control, and reinforces existing inequities.

Our research revealed emerging themes, which we categorized as the positives and the negatives. The positives include: (1) From a "dumping ground" to a "safety net"; (2) I don't want

\footnotetext{
${ }^{1}$ We use the term "school program" as teachers in our research site refer to their school as an "alternative program."
} 
to go back to the regular high school. Three themes are identified in the negative category, which require scrutinizing the school more carefully. They are: (1) I want to go to college; (2) I don't like the new building, and (3) We are left out of everything. These themes are significant because they indicate the successes and failures of the school. We found that the school is successful in providing a caring environment for the students and gaining trust from the students (Noddings, 2005; Rogers \& Freiberg, 1994). However, the school fails to offer an alternative as described by Conley (2002) that encourages the students to achieve their goals by providing the equitable education that they need. This failure leads us to question for whom this school is an alternative.

The significance of our study resides in that: (1) it points out that a caring and safe learning environment does not necessarily guarantee an equal and equitable education. In other words, an ethical ideal to the experiences of caring must be nurtured through dialogue, practice, and confirmation (Noddings, 2005); (2) it reveals that it is not only students but also teachers in alternative schools that are marginalized by mainstream education; and (3) it points out the importance of including the voices of students and teachers in planning and implementing school changes, which requires policy makers to reconsider their hierarchical decision making practice that is pervasive in the educational system in general. It is our hope that our research outcomes will contribute to developing more successful and effective alternative education practice, thereby making a contribution to enhancing social justice.

In the following, we will discuss more specifically our theoretical framework, research site, research methods, results, discussion and implications, and conclusion, respectively.

\section{Theoretical Framework}

In this study, we employ critical theory as our theoretical framework. Critical theory, as it originated from the Frankfurt School, provides a number of valuable insights for studying the 
relationship between theory and society (H Giroux, 2001). Critical theory refers both to a school of thought and a process of critique with regard to notions of money, consumption, distribution, and production, all of which are promoted by relationships of domination and subordination. According to Giroux (2001), critical theory stresses the importance of critical thinking by arguing that critical thinking is an indispensable feature of the struggle for self-emancipation and social change. While arguing against the suppression of subjectivity, consciousness, and culture in history, critical theory also examines the contradictions of society rather than social harmony. For critical theorists, the ability to look at the contradictions of the society and education in particular, is considered a starting point to develop forms of social inquiry that question what is in reality versus what should be. The rationale undergirding critical theory supports the idea that action should be grounded as Marcuse argued, "in compassion, [and] in our sense of the sufferings of others" (cited in Giroux, 2001, p. 9). According to Giroux:

$[t]$ he concept of critical theory refers to the nature of SELFCONSCIOUS CRITIQUE and to the need to develop a discourse of social transformation and emancipation that does not cling dogmatically to its own doctrinal assumptions. . It points to a body of thought that is, in my view, invaluable for educational theorists; it also exemplifies a body of work that both demonstrates and simultaneously calls for the necessity of ongoing critique, one in which the claims of any theory must be confronted with the distinction between the world it examines and portrays, and the world as it actually exists (Giroux, 2003, p. 27-28, capital letters in original).

Critical theory is central in addressing our research question because it helps us understand what is happening in the alternative school versus what should be happening. Importantly, it questions who benefits from the current educational practice. Thus, the focus of 
our analysis is what is going on in the alternative school versus what should be going on in order to eliminate social control and social reproduction, thereby promoting social justice. In other words, we want to examine what should be done to break the cycle of inequality that is manifested in alternative school populations comprised of marginalized groups in terms of class, gender, and race. Through the lens of critical theory in our data analysis, we examine the ways the alternative school in the study functions either to thwart students' aspirations and goals or to encourage them to achieve their goals. In doing so, we seek to determine whether or not this alternative school is, in fact, beneficial to the students, contributing to breaking the cycle of educational inequality.

\section{Research Site}

Our research site, Prairie Alternative High School (pseudonym), is located in a district that has a high minority student population given its Midwest location and the population of the town. The nearby military base contributes to the area's diversity as well. The student population is comprised of $60 \%$ students of color. Seventy percent of the students receive free or reduced price lunch. The school was started approximately 25 years ago as an alternative education center for truancy students and students involved with the court who were not experiencing academic success at the regular high school. The school serves 40 students from ninth through

eleventh grades who are behind in credits for graduation. Currently, the school employs full time four teachers, two females and two males, who teach math, science, English, and social studies; two administrative assistants; a secretary; a clerical support person; a resident janitor, and several paraprofessionals. The Associate Superintendent of the school district is the Principal of the school. 
According to the school administrators, Prairie is an exemplary alternative school for students who were not successful in the traditional school. The program of this alternative school is so well known that another high school in the State adopted the program and created an alternative program modeled after Prairie. During our first meeting with Associate Superintendent, Dr. Dix, he explained the scope and depth of the school district's All Can Achieve Innovative Programs (ACAIP), Pre-Natal through High School Graduation. His pride in the alternative school contradicted our preconceived notion that this alternative school would provide an oppressive environment, as do many other alternative schools (Kelly, 1993; Kim, 2006). In fact, Dr. Dix's description of the school reminded us of Rogers' work. Rogers (Rogers \& Freiberg, 1994) visited schools that, "did a particularly good job of serving students who have traditionally been underserved by our educational system in the past" (p. 5). He traveled to six diverse major cities in the early 1990s interviewing students from a cross section of cultures and ethnicities in schools. Those schools included alternative schools such as Montefiore School for troubled boys in Chicago; New Orleans Free School; Milby High School in Houston; O’Farrell Community School in San Diego; and Clement McDouough City Magnet in Massachusetts. He identified eight consistent common positive characteristics about the learning environments among students. From numerous interviews and through the facilitation of the teachers and the learning environments they created, the eight characteristics identified by the students were: (1) students want to be trusted and respected, (2) students want to be part of a family, (3) students want teachers to be helpers, (4) students want opportunities to be responsible, (5) students want freedom, not license, (6) students want a place where people care, (7) students want teachers who help them succeed, not fail, and (8) students want to have choices. Noddings' (2005) theory of care lends further definitive support to the value of establishing caring relationships in schools. 
Although wanting a place where people care is more simplistic than Noddings' theory, it provides a basis to begin and work toward her more comprehensive conceptualization.

Dr. Dix also described the changes in the program. In January 2003, the program changed to a full-day program that runs from 7:45 a.m. to 2:30 p.m. Its focus is on Project Recovery, which is designed to assist students who are behind on credits leading to high school graduation. The school's singularly focused aim is to provide an environment where students catch up on high school credits so they can return to the regular high school for their senior year and graduation. This is represented by the school's mission statement, "To provide identified students an alternative opportunity to continue to earn academic credit in a structured school environment" (School Handbook).

In March 2006, while this study was being conducted, the alternative school moved into a $\$ 2.5$ million remodeled Alco building and was renamed the Center for Innovative Studies. The new name did not contain alternative school because the administration sought to minimize the negative perception that the neighborhood has about the alternative school. The new building has a modern appeal with light green walls inside the building and high ceilings. Each classroom is spacious and well lit with glass walls exposed to the hallway rather than solid walls. Each classroom has a sink, storage cupboards, five computers for students, and a video camera that videotapes classes for the purpose of documentation in the event of a disruption by a student. The social studies room also has a Smart Board and LCD projector. Several of the teachers placed curtains over the windows to provide more privacy for their classes. There is a main office with three adjoining administrative offices and a conference room, a spacious cafeteria and lockers, the opportunity room with at least ten computers, and another spacious classroom that is used primarily for the after school program, called 3:15 to 6:15 p.m. Program. 


\section{Research Methods}

This research is a qualitative case study, which concentrates on the experiential knowledge of the case, Prairie Alternative High School, and pays close attention to its activities and phenomena (Stake, 2005). The research methods employed in this study were classroom observation with field notes; open-ended, structured interviews with students, teachers, and administrators; analysis of primary documents such as curriculum materials in four classrooms of science, social studies, math, and English. Observations were done twice a week for three months from February to April 2006. Interviews were structured in that all the interviewees were given the same series of pre-established questions before the interviews (Fontana \& Frey, 2005). However, we allowed ample room for variation in response because the questions were openended, thus, the interviews sometimes became conversational (Kvale, 1996). We took an "empathetic approach" to our interviews, i.e., "an ethical stance in favor of the individual or group being studied" (Fontana \& Frey, 2005, p. 696). We interviewed nine students, four teachers, one school administrative assistant, and one associate superintendent. Each interview lasted an hour and a half and was tape-recorded and transcribed. Interviewing people in different positions of power provided us with multiple perspectives about the school program. We considered students' perspectives as particularly important. As Giroux (2001) notes, students who are marginalized by class, race, and gender seldom are invited to engage in educational discourses and pedagogical practices that shape their everyday lives:

Working class students, women, Blacks, and others need to affirm their own histories through the use of a language, a set of social relations, and body of knowledge that critically reconstructs and dignifies the cultural experiences that make up the tissue, texture, and history of their daily lives (Giroux, 2001, p. 37). 
By paying attention to students' perspectives, our purpose was to use the results to find ways to provide better educational opportunities for disenfranchised students.

Denzin (1994) points out that even the so-called objective writings of qualitative research are interpretations, not value-free descriptions. As such, our biases entering into the research are identified as: (1) the environment would parallel that of the Borderlands study that reveals the oppressive educational atmosphere where marginalized students continue being disenfranchised by power and control (Kim, 2006); (2) that the curriculum would parallel that of Freire's (1997) banking concept and not be beneficial to the students, and that (3) the school and its curriculum would not represent educational equity for its students.

Interview protocol questions are listed in Appendices 1, 2, and 3. Both of us coded the same data, i.e., interview transcripts and field notes, separately to establish internal validity or credibility (Anfara, Brown, \& Mangione, 2002). We used what Glaser and Strauss (1967) call, constant comparative analysis in which the data were compared and categories and emerging themes were identified or integrated together using "in vivo" codes to honor participants' expressions and language. The data then were triangulated to ensure trustworthiness of the data (Stake, 2005). Table 1 shows how multiple sources of data collection as well as multiple voices - the voices of teachers, students, and administrators, were used to triangulate the data for this study.

Table 1. Matrix of Findings and Sources for Data Triangulation

\begin{tabular}{|c|c|c|c|c|c|}
\hline \multirow[b]{2}{*}{ Major Finding } & \multicolumn{5}{|c|}{ Source of Data } \\
\hline & SI & TI & AI & $\mathbf{O}$ & D \\
\hline \multicolumn{6}{|l|}{ Category 1: The Positives } \\
\hline 1. From a dumping ground to a safety net. & $\mathrm{X}$ & $\mathrm{X}$ & $\mathrm{X}$ & $\mathrm{X}$ & \\
\hline 2. I don't want to go back to the regular high school. & $\mathrm{X}$ & $\mathrm{X}$ & $\mathrm{X}$ & $\mathrm{X}$ & \\
\hline \multicolumn{6}{|l|}{ Category 2: The Negatives } \\
\hline 1. I want to go to college. & $\mathrm{X}$ & & & $\mathrm{X}$ & $\mathrm{X}$ \\
\hline 2. I don't like the new building. & $\mathrm{X}$ & $\mathrm{X}$ & & $X$ & \\
\hline
\end{tabular}


3. We are left out of everything.

Note $. \mathrm{SI}=$ Student Interview, $\mathrm{TI}=$ Teacher Interview, $\mathrm{AI}=$ Administrator Interview, $\mathrm{O}$ = Observation, $\mathrm{D}$ $=$ Document

Before the students were selected, we visited at length with Mr. Huff, the Administrative Assistant, about student selection. We identified our interest in interviewing students who attended the school for different amounts of time and who represented a variety and cross section in terms of gender and ethnicity. Because they can not remain in the school for more than two years, we wanted to compare the students' experiences between the first and second year students. Mr. Huff recommended three first year students and five second year students because they were transitioning well into the alternative school setting, their attendance was regular, and they represented a mix of gender and ethnicities. Smiley volunteered later to be interviewed. She strongly expressed her willingness to share her alternative school experiences with us.

Student participants ${ }^{2}$ we interviewed are: (1) Smiley is a 16-year old Hispanic, female freshman. She came to the alternative school from Arizona, returned to Arizona, and again returned here; (2) Tarkeisha, an African American eleventh grade female from Chicago, has been at the alternative school for two years; (3) Nook, an African American ninth grader in his first year at the alternative school, who has lived in Washington, D.C., Georgia, and Germany; (4) Yancy, a white sophomore male who wants to drop out of school after this year and get his GED; (5) Durrell, an African American male junior in his second year at the alternative school; (6) Tom, a half-Irish and half-Native American, 17 years old, who is in his second year at the alternative school; (7) Christina, an African American 17-year-old female who is in her second year at the alternative school; (8) Felicia, a White female 15-year-old student who is in her first

\footnotetext{
${ }^{2}$ Some of the names used in the study are pseudonyms.
} 
year at the alternative school; and (9) Emily, a White 16-year-old female student in her first year at the alternative school. Table 2 summarizes the student participants.

Table 2. Student Participants ${ }^{3}$ from the Alternative School

\begin{tabular}{|l|l|l|l|l|}
\hline Student & Age/Grade & \multicolumn{1}{|c|}{ Ethnicity/Race } & \multicolumn{1}{c|}{ Year at } \\
Smiley & 16 & Hispanic & Female & \multicolumn{1}{c|}{ Alternative School } \\
\hline Tarkeisha & 11 th Grade & African American & Female & Second year \\
\hline Nook & 9th Grade & African American & Male & First year \\
\hline Yancy & 10 th Grade & White & Male & Second year \\
\hline Durrell & 11 th Grade & African American & Male & Second year \\
\hline Tom & 17 & Half Irish/Half Native American & Male & Second year \\
\hline Christina & 17 & African American & Female & Second year \\
\hline Felicia & 15 & White & Female & First year \\
\hline Emily & 16 & White & Female & First year \\
\hline
\end{tabular}

We interviewed all four teachers at the school. They are: (1) Mr. Bard, a white male who teaches social studies and who has been at the school for five years; (2) Mrs. Burg, a white female who teaches English and who has been at the school for 11 years; (3) Mr. Bay, a white male who teaches mathematics and who has been at the school for nine years, and (4) Mrs. Land, a white female who teaches science, has taught for a total of 17 years and has been at the school for seven years. Table 3 summarizes the teacher participants.

Table 3. Teacher Participants at the Alternative School

\begin{tabular}{|l|l|l|l|c|}
\hline Teacher & Ethnicity/Race & Gender & \multicolumn{1}{c|}{ Content Area } & $\begin{array}{c}\text { Tenure at } \\
\text { Alternative School }\end{array}$ \\
\hline Mr. Bard & White & Male & Social Studies & 5 years \\
\hline Mrs. Burg & White & Female & English/Reading & 11 years \\
\hline Mr. Bay & White & Male & Mathematics & 9 years \\
\hline Mrs. Land & White & Female & Science & 7 years \\
\hline
\end{tabular}

${ }^{3}$ Each participant in this study self-identified their background information, i.e., ethnicity and age. 
In terms of the administrator participants, we interviewed Mr. Huff and Dr. Dix. Mr. Huff, Administrative Assistant, is in charge of running the school, taking care of issues that daily occur at the school, such as students' behavioral issues, parents' visits, and other management issues. He has worked at the school for 18 years. Dr. Dix is an Associate Superintendent and the Principal of the school. He is the one who gave us a permission to do research in his school. Table 4 describes the administrator participants.

Table 4. Administrator Participants at the Alternative School

\begin{tabular}{|l|l|l|l|c|}
\hline Teacher & Ethnicity/Race & Gender & \multicolumn{1}{c|}{ Position } & $\begin{array}{c}\text { Years at } \\
\text { Alternative School }\end{array}$ \\
\hline Mr. Huff & White & Male & Administrative Assistant & 18 years \\
\hline Dr. Dix & $\begin{array}{l}\text { African } \\
\text { American }\end{array}$ & Male & $\begin{array}{l}\text { Associate Superintendent/ } \\
\text { Principal }\end{array}$ & 4 years \\
\hline
\end{tabular}

\section{Results}

In answering our research question-In what ways is the school curriculum beneficial or not beneficial to the students in terms of equity - we categorized our data into two parts based on the emerging themes: the positive views and negative views. The positive views include, (1) from a dumping ground to a safety net, (2) I don't want to go back to the regular high school. The negative views were, (1) I want to go to college, (2) I don't like the new building, and (3) We are left out of everything.

\section{The Positives}

Two salient themes emerged from the coding process, which support the claim that the alternative school, in fact, benefits the disenfranchised students in certain ways. The two themes are (1) From a dumping ground to a safety net, and (2) I don't want to go back to the regular high school.

\section{(1) From a Dumping Ground to a Safety Net}


According to the teachers, the alternative school formerly housed students who dropped out of school, who were delinquents, and who violated school rules and regulations. This created the school's reputation as a dumping ground for the kids who were unwanted and unwelcome at the regular high school. These students were the ones who were overlooked in the regular high school and left to fend for themselves. It used to be a school where teachers in the regular school sent troublemakers in their classrooms in order to "get them out of their hair."

Mr. Bay, the math teacher, who has been teaching for nine years at the school, said:

Well, basically, the alternative school, to me, was kind of a 'dumping ground.' If you had some trouble makers in your classroom, you would say, why don't we send them to alternative school? And that was what everybody was saying. It was a place for them to go, you know, kind of get them out of our hair. Now, they [students] are here because they are behind in credits. We are trying to get them back to where they should be, which is called credit recovery. This is a safety net, you might say... so to get them back on track, but then, in a small atmosphere, less numbers.

Mrs. Land, the science teacher, also commented:

It [the school] quit being a 'dumping ground.' There are a few of the kids that still have behavioral problems, but I think students realize that it is not entirely that. And they don't feel the stigma that they felt in the past about it. They [regular schools] are pretty particular. They don't send us the really bad delinquents here any more.

Mr. Bay's and Mrs. Land's comments reflect the effects of the change that the school does not accept delinquents any more, rather, students are here because they are behind in credits. Their comments show that the school stopped being a dumping ground since the school changed its program focus to credit recovery. 
Dr. Dix explained that these changes were made at the school district level eight years ago. Under the leadership of two consecutive superintendents, the school revamped its program to focus on credit recovery to help students who were behind in their academic credits. The school program became more structured with a specified curriculum goal and restricted the number of students who could attend. Students with behavioral problems are sent to the after school program called 3:15 to 6:15. These delinquents must attend this after school program for a week and show improvements in behavior. Because of the change to focus on credit recovery, the alternative school does not seem to have many behavioral problems as noted by the teachers and from our observations.

Another contributing factor to the improved school image from a dumping ground to a safety net is the program change from a half-day program to a full-day program in 2003. Before the alternative school implemented a full-day program from the half-day program, merchants in the community complained about the students who were out on the street doing things that they should not be doing after school. Since having students at school for a full day until 2:30 in the afternoon, complaints significantly subsided, gaining more positive recognition from the community. Students likely were influenced by the community's negative perceptions of the school and their views paralleled those of the community, thus creating a desire to avoid the negative association. Some of the students already had unconstructive experiences at the regular high school where they were labeled negatively. The labeling disenfranchised them further from the regular high school. However, when given no choice about attending the alternative school because they were behind in credits for graduation, their perceptions of the school changed once they were there. Students expressed how much they hated to be placed at the school, but after attending the school for a while, they believe that it is a good place for them. Tom said: 
Before I got here, they said to me, 'You are going to have to go to the alternative school next year. I was like, 'Don’t send me there [alternative school]. I will do anything, I will go to summer school, I'll stay after school, I will do anything, please do not send me there.' But they did. On the first day here, I was all mad. I was just like, 'I hate this place.' It was like a place where you never want to be. Everybody told me bad rumors about the school. This is the worst place you can go to. But now I like everything here in this school. If I don't like it I will stay away from it. If I didn't like anything here I would probably be doing exactly what I was doing in high school.

From our observation, Tom seemed to be having a positive experience at the school. He always sat beside his girlfriend who tried to help him focus on classroom tasks. He was highly spoken of by his teachers for his changed behavior.

All the interviewees, both teachers and students, believe that the school is trying to work as a safety net for these disenfranchised students so they could go back to the regular high school to graduate. Our next emerging theme, however, shows that students do not want to go back to the regular high school. They want to graduate from the alternative school with a high school diploma.

\section{(2) I Don't Want to Go Back to the Regular High School}

The goal of the alternative school is to have students on grade level in math, science, social studies, and English, so the students can return to the regular high school for their senior year and graduation. The policy is that students can stay at the alternative school for the two year maximum. However, all the student interviewees expressed that they wanted to stay at the alternative school until their graduation. Tom is one who has to leave the alternative school next year. He said: 
Everybody has been really good to me. In the beginning of my first year here, I didn't want to do anything. But they [teachers] stuck with me and made sure I was going to do my work. They knew I wanted to learn and they helped me through all that. And now I don't want to leave because they have been too good to me.

Tom indicated that it was the school environment created by caring teachers as the reason he wanted to stay at the school. Although Tom did not want leave the alternative school, the school regulations required him to return to the regular high school.

Christina echoes Tom's sentiments and also likes the alternative school better: "Actually, I kind of like it over here a lot better, I don't want to go back to high school."

Tarkeisha could have attended the regular high school but made the choice to return to the alternative school after her first year at the alternative school. Although she has ambivalent feelings about her choice, she also acknowledged that the school has helped her:

I had the opportunity to go to the [regular] high school, but I chose to come back here because I thought it was better here for me than to be at the [regular] high school. ... It's [alternative school] a good deal for me. It's easier. It keeps me focused more than I think I would be at the [regular] high school. When I got here, everything was hard. But now, it's like I am racing through stuff, so it is really easier.

Tarkeisha's statement is noteworthy because she made a conscious choice to come to the alternative school because she believed it would be better for her. From our observations, she was more engaged than other students, indicating that she was well adjusted to the school.

In contrast to Tarkeisha, Durrell was told he had to attend the alternative school. He said, "They [regular school administration] said I had to come here. So I came here and for some reason I liked it. So I just wanted to stay." Later in his interview, Durrell said that his favorite 
thing about the school is the teachers and "how everybody knows each other." In spite of the mandate for Durrell's attendance, he ultimately liked the school, its environment, and the teachers.

Another student, Yancy, made a comparison between the school and his former regular school, describing the regular high school as a place where they are "more stuck up":

They [regular high school] will label you at the beginning of the year. Even when you do your work and you change, they still label you. But down here [alternative school], they help you no matter what, unless you are sent out of class every day. They are good. If I wasn't going to drop out of school after this year, I would come back here because it is a lot easier than the [regular] high school. You get more help here. We spend more time on what we are doing than at the high school. Here they go slowly and step-by-step and so it is easier. Like graphing, we spent two and a half weeks on it and that way we know it. When we did the test, almost everybody passed it.

Yancy emphasized the extra help he receives from the teachers at the alternative school. His positive experience reflects in part what a progressive alternative school should strive to achieve, e.g., individual attention, teachers' willingness to help, and adjusting the pace of instruction for the student ensuring student understanding.

Students' narratives show that they do not want to return to the regular school, but stay at Prairie as long as they can. They know how much teachers and the staff care about helping them succeed. What Mr. Huff, the Administrative Assistant, says below affirms the students' perceptions:

I really want to stay. It would take a bomb to get me out of here. I really love what I am doing. ... What keeps me here? The love of those kids. The love of kids. I look at it as 
someone has given up on these kids somewhere in their life. . Now for whatever reason, I am not going to be that person. I am not going to be the last person that says you are going to have to go out the door. . . And that is what keeps me here. I want to see these kids make it, be successful, and become a contributing member of society.

Mr. Huff's love for the students and his commitment to their success seems to positively influence students' desire to remain in the school. The teachers' tenure at the alternative school as noted in Table 2 demonstrates their satisfaction with teaching there too.

These positives indicate that Prairie provides a constructive experience for the students. Administrators and teachers believe that they are providing the education that these students need, and students believe that they are doing a better job than they did in previous schools. Since Dr. Dix started sending students with behavioral issues to the After School Program, both teachers and students think that they can focus on learning without interruption. These positives confirm why this program is well known in the State and has become a model program for other school districts.

\section{The Negatives}

It is encouraging that students, teachers, and school staff expressed in unison that their experience at this alternative high school has been positive. However, three themes that require scrutinizing the school more carefully emerged. They are: (1) I want to go to college, (2) I don't like the new building, and (3) We are left out of everything.

\section{(1) I Want to Go to College}

Unlike the common belief that alternative students do not wish to go to college, students we interviewed want to go to college to achieve their dreams. Regarding her desire to attend college, Felicia said: "None of my family went to college. But I have better plans. I want to go to 
college, and if I can't afford to go to college I'll work like at a motel or whatever, and pay for college." Tarkeisha, who has been at the alternative school for two years, identified her goal as, "I want to be a pediatrician. I kept saying that since I was 6 years old. I want to go to college. My cousin is going to [college] for medical school." Smiley said, "I want to be an architect. I want to design houses. That is my goal, to become an architect. I'm going to finish college. . I want to start college right after I finish high school." Nook described his goals, "My goals are playing high school football and going to college. My grades are up. I got straight As and Bs." Christina expressed her realization that she needs to attend college: "I don't mind learning. I like math. I just try my best because I know I will have to go to college one day." Emily, who wants to be a writer, said, "I really just want to graduate from the high school, and not disappoint any of my family members. I do want to go to college. I want to further my knowledge."

It is clear that students at this alternative school have hopes, dreams, goals, and aspirations for their futures. They identify a college education and their realizations of its importance. In contrast, Associate Superintendent Dr. Dix's expectations for the students are different. He believes that reading and math are the most important subjects. With reading and math as the emphasis, he believes the students then can do well enough to get by in science and social studies. According to him, these core basic courses may not prepare the students to become a nuclear engineer, but then, he rhetorically asked, "How many kids at the alternative school want to be a nuclear engineer?" Although the students interviewed did not identify nuclear engineering as a career goal, their aspirations included, for example, the medical field and architecture. Their dreams require a more rigorous college-bound curriculum and career counseling. However, the students are not receiving such counseling at the alternative school, nor are these elements part of the school's stated purpose or vision. Dr. Dix clearly possesses the 
traditional, positivistic perspective wherein the perceived role of schools as instrumental adjuncts of the workplace impose 'technocratic rationality' on students to sort them (Apple, 2004; Eisner, 2001; Greene, 2003). Even though the school's focus on credit recovery may help the students graduate, the school needs to offer a rigorous curriculum beyond the credit recovery.

For example, one curricular program used extensively in the alternative school is the A+ program for students' credit recovery, which is a computerized curriculum. Some teachers were critical about it. According to Mr. Bard, it is an easy way for the students to recover credits. Students can go back to the same questions repeatedly until they know the right answer. Some students just write the answers down to ensure they answer them correctly. With this program, students can earn a half credit in a week. Mr. Bard said, "I have seen kids flunk a semester from a regular school and come down here [alternative school] and get credit in two days. What kind of integrity does that build?" Although the A+ program may build some students' self-confidence because they can earn credit in a short period of time, Mr. Bard's question makes a significant statement about it.

What is interesting, though, is some students think that the A+ program is good for them. They are proud that they are earning credits and getting better grades than they did in the regular high school. They gain self-confidence and a sense of empowerment and control over their lives and learning. They realize that they can learn and are not "stupid." Smiley said:

Now I have been doing A+. I have been doing good. I should have about seven and onehalf credits at the end of this year. I am happy. My grades are really good and I am just proud of myself. I never thought I would do this good. I figured that I would get an F or something and not accomplish what I wanted to do. 
It seems that credit recovery is favored by some students because they can earn credits in a fairly short time. This is revealing in the sense that credit recovery is not about meaningful learning, rather, it is about "getting it over with" as quickly as possible while still earning a good grade by repetition or just memorizing the answers. It is highly skeptical whether meaningful learning is taking place when the A+ curriculum is implemented as a "quick-fix."

The four teachers teach the core basic courses of reading, math, science, and social studies. In fact, the curriculum is supposed to be the same as the nearby regular high school, i.e., adopting the same textbooks. Reasons for using the same curriculum are: (1) it is easier to make comparisons based on standardized test scores between the students in the alternative school and the high school, and (2) when the students go back to the high school, it is easier for them to fit into the regular school program. However, in reality, the alternative school focuses on remedial classes for students since they are at the fourth and fifth grade levels in math and reading.

From our observation, teachers hardly use high school textbooks with the exception of the social studies teacher. They mostly rely on curriculum materials such as handouts and worksheets. Computers are integrated into teaching and learning in all of the four core classes. Each classroom has four or five computers that students can use. Mr. Bard, the social studies teacher, integrates movies, the Internet, field trips, and other formats that provide variety and multiple modes for understanding. Mr. Bay, the math teacher, tries to individualize the instruction by giving students individual tutoring whenever they have questions. Ms. Land, the science teacher, creates her own lessons, without relying on the textbook. Mrs. Burg, the English teacher, relies heavily on canned curriculum, called Read 180. There was scarce evidence of rigorous curriculum or instruction that the regular high school offers. The only cooperative groups or paired work observed were for worksheets. Nevertheless, especially given the small 
class sizes, there is the potential for opportunities for other learning configurations that are ignored.

Our interview transcripts reveal that students receive some counseling for work study. They are advised to participate in something similar to job shadowing without pay. These jobs do not require students to further their educations after high school. They are for practical purposes, which track students to a technical/vocational setting or no further education at all. As such, students do not receive any counseling for college. Moreover, although not implemented during the time of our observations and research, Dr. Dix described plans for the 2006-2007 academic year for one elective course the alternative school would offer the students to work at Job Corps. The school was entering into a contract with Job Corps, which would provide transportation to and from the school, pay students $\$ 150.00$, pay an additional $\$ 25.00$ every two weeks for being enrolled in the classes, a clothing allowance if students need special clothing for the course they are taking, and $\$ 250.00$ to students who complete the Job Corps program and graduate with a high school diploma.

To Dr. Dix, job training is relevant to students. For him, relevancy means that students must relate their education to their future job world. He said: "So that is the kind of vision I have. To me, it is going to make school more real to these kids, more than anything we can do in the classroom." Additionally, his focus is on external rewards for students, rather than cultivating their internal motivation and desire to learn for understanding. Dr. Dix believes that to make the curriculum culturally relevant to students or that considering students' different learning styles is not necessary because, (1) it is impossible to meet every individual's different needs and interests, and (2) it is not the way the society operates. He perceived that math and science are not conducive to integrating culturally responsive teaching, which is a mindset that continues to 
create learning environments that are not personally meaningful to students and perpetuates disenfranchisement and marginalization. He also believes that students have to be prepared for the real world to remind them that there is no alternative work world.

\section{(2) I Don't Like the New Building}

The second theme that emerged in terms of the negative perspective is that students do not like the new building. In spite of a 2.5 million dollar initiative by Dr. Dix and the district to move into the renovated building housing the Center for Innovative Studies, an interesting general consensus among teachers and students about the new building was negative. The reasons why they do not like the new building are: (1) it is like a school, (2) it is too big, and (3) it has too many different programs. Change often is difficult for people of all ages. There were mixed feelings by students when the preparations were underway for them to move to the new building. The old building was where their ties were formed and solidified. Overall, students felt that the old school was more like a home than a school. They expressed definite opinions about their dislike of the new facility. Christina said that:

I don't like this new building because it is like a school. Our old school building was smaller and we were comfortable. This is like an actual school building. I feel like they have put me back in the high school. It is more open, and too much space. I like it when it was smaller.

It is interesting to hear that Christina does not like the new building because "it is like a school," which implies that she did not have a good "school" experience.

Tarkeisha compared the old school to a home:

No, I can't stand it [the new building]. I would rather be back in the old building because it is homey. We were closer together there [the old school] than we are now. They got a new 
building, new attitudes, and new rules. They just started coming up with their own rules and not doing what the Handbook says, but doing what they want.

Tarkeisha's feeling about the old building is confirmed by Durrell who commented on feeling closer in the old school. It is likely that his reference is to the closeness felt by a family:

It's not like the old building. The old one, it seems like we were closer. This one has everybody spread out. It don't seem like hardly anybody likes it. ... I don't like it [new building]. I want to go back to the old building.

Yancy gave a somewhat contradictory account describing his feelings about the new versus old school. He began by identifying some of the things he likes about the new school, but then counters with the things he misses about the old one:

It is bigger [new building]. There is a lot more room for the classes and we have a bigger cafeteria. At the old school there was a refrigerator and a microwave you could use and here you can't. We used to be able to bring stuff from home and pop it in the microwave. It was an unexpected finding that students' had negative feelings about the new building as indicated in their above narratives. Further, it represents a common administrative practice of planning and implementing initiatives without involving the stakeholders in the decision making process - in this case, the students and the teachers.

Another change that came with the new building is that students have to share the new building with the middle school students who also are behind in their credits for graduation. As the alternative school moved to the new building, students and teachers experienced not only the challenge of getting used to the new physical building, but also the challenge of middle school students being incorporated into the setting. When the building is completely finished next year, the school also will house the Head Start program and become complete as the Center for 
Innovative Studies. Most students expressed their discomfort with the change in the program, particularly with the inclusion of the middle school students and the adjustments required because of their presence. Yancy said:

I don't like the middle schoolers being here because they are all loud and we get in trouble. We had to close the bathrooms a couple of times because the little kids mess it up. We can't do a lot of stuff now that we used to do, like run around It will get too out of hand. We are supposed to set an example for the little kids. We can't do what we want to now. We had a lot more freedom at the old school.

Christina dislikes having middle school students in the building:

This is like an actual school setting. Now, we've got the middle schoolers and second chance people. We have too many different people. I liked it when it was smaller and didn't have the middle schoolers in it. They cause more trouble and they are in the hall and I don't like that part. It's like they ask for trouble.

Both Yancy and Christina's narratives expressed resentment about having the middle school students in the same building. The presence of the middle school students, in combination with the new building, made them feel that they were in the regular school rather than the closeness they felt in the old building.

Teachers also expressed their dissatisfaction about the building. They were not consulted about their classroom layout, equipment location, and the grounds surrounding the new facility. It does not have a gym. Mrs. Land, the science teacher, pointed out that the new building is not necessarily better because it is surrounded by asphalt with no room outdoors for physical or class activities. She told us how much she liked to take students outside the old school building as a part of her classroom activities. The teachers' dislike of the new building exposes another 
significant finding. They feel disenfranchised because they were not included in the planning and implementation of the new facility. This feeling of disenfranchisement is further expanded in our next emerging theme.

\section{(3) We Are Left Out of Everything}

It is an interesting discovery to learn that the alternative school teachers feel like they are treated as second-class citizens. They are discontent with how they are treated by the school district. This discontent should not be ignored because it exemplifies another inequity in the alternative school. Teachers at the alternative school state that they are not provided with the same opportunities for professional growth as the teachers in regular school in the same school district. When teachers have a district meeting, alternative school teachers feel like outsiders. They find that they have little to do with regular teachers except when there is a problem kid to send to the alternative school. The e-mails the alternative school teachers send to the district making suggestions are ignored. For example, it takes the school district three or four months before anyone comes to the alternative school to fix the problems. Technically, this alternative school is considered part of the nearby regular high school. Even though they are two different schools, the administration of the alternative school is under the high school. However, according to Mr. Bard:

This is the thing, the problem with alternative schools is that it is the dead end career wise. In this school district, we are left out of everything. Everything. I mean, I haven't been to a workshop, seminar, or anything since I have been in the alternative school. I don't get informed about it.

It is quite a provocative statement when he said it is "the dead end career wise." During the interview, he expressed his aggravation about being unequally treated by the school district. He 
also expressed his frustrations about some of the practices at the alternative school. According to Mr. Bard, this alternative school houses the left-over teachers from regular schools.

Paraprofessionals secure employment at the alternative school, not by their qualifications, but by whom they know. There was one paraprofessional at the school who was shuffled off from the high school because of sexual harassment. He was at the alternative school for a while last year, but he ended up in jail. Mr. Bard shows his discontent with the administration. He said:

We have too many administrative conflicts. It is not a team effort here I don't think. I don't know what the program is going to like for sure or not. What we decided on last year is not the same thing we have now.

Mr. Bay echoed what Mr. Bard had to say:

As an alternative school we are told over and over and over, we don't have to do everything exactly like the high school, but you turn around and they try to model us after the high school. So we don't want to take any chances. And when we have in-services, we want to try new things, and make plans. But we turn around, we are going back to the same grind.

The teachers' comments caused us to reconsider the positive view of how this school changed from a dumping ground to a safety net. Even though the administration worked to change the perception of the school, which seems to be somewhat successful, we must be attentive to what the teachers' feelings are about their positions at the alternative school. It should be noted that teachers still feel that they are not treated as equally and equitably as those in the regular school. As such, we revisit Kelly's (1993) argument, i.e., students in the alternative school are treated as second-class citizens of education. Our findings indicate that it is not just students, but also 
teachers who are treated as second class citizens of education, which represent relationships of domination and subordination.

\section{Discussion and Implications}

Critical educators who work toward social change endorse theories that are dialectical, i.e., theories that "recognize the problems of society as more than simply isolated events of individuals of deficiencies in the social structure" (McLaren, 2003, p. 69). McLaren's statement implies the problems that occur in the school structure mirror those in the social structure at large. Hence, we also believe that educational problems are created in an interactive context between the school structure and the students who respond to it, which is opposed to the deficit thinking paradigm we described in the Introduction. Although we cannot argue that our findings represent the views of all students at Prairie Alternative High School, their implications are significant in that they demonstrate consistent views among the participants and the field notes from our observations.

Through our data analysis, we discovered that the school is providing a caring environment where the students feel comfortable. This positive school experience for all the participants is demonstrated through (1) the changed perceptions of the school from a dumping ground to a safety net, and (2) students who first hated the school now feel that the alternative school is a good place for them and they want to graduate from there. These changed perceptions imply that the school program is beneficial to the students in the sense that it offers a safe and caring environment for the students, which they need in order to succeed in school. Students have a good relationship with teachers who are caring, understanding, and respectful. Teachers and students feel that they are part of a family in the small school environment, a feeling that they hardly experienced in the regular high school. In this small school environment where only six to 
ten students are in each classroom, they know each other well enough to feel a sense of belonging. School is a place where they felt welcome and invited. Teachers are successful in gaining trust from students who believe that teachers are there to help them succeed. Students consistently identified characteristics displayed by teachers and staff at the alternative school that represent respect, caring, honesty, genuineness or realness, and trust (Rogers \& Freiberg, 1994).

However, on a deeper level, the school seems to lack systemic support that would break the cycle of educational inequality. For this alternative program to succeed in providing equal and equitable educational opportunities for these students, therefore, contributing to breaking the cycle of educational inequality, the school needs to reconsider its program and provide more integral, systemic support discussed below.

First, Prairie needs to provide more rigorous curriculum that emphasizes critical thinking, synthesis, and higher order thinking, which, in turn, will help the students to achieve their goals. Our data show that the curriculum is behavioristic and reductive in that it remains at a lower level that only helps them recover the credits needed for graduation or to obtain the basic skills, which is a common practice that goes on in schools that serve low income, marginalized groups of students (Anyon, 1980; Dance, 2002; Fine, 1991; Oakes, 1985). For instance, the A+ program that is supposed to help students recover the credits does not represent real learning or understanding. It is a mechanistic drill with numerous flaws. Not only is it devoid of the meaning of why what they are learning is important, it also lacks interaction between the teacher and students and students and their peers. Its purpose seems to be a "quick fix" while failing to build integrity of the students. It does not position students in engaged, deep, meaningful learning for understanding, or higher order critical thinking. This represents Freire's (1997) banking education where students are considered passive receptacles and learn how to get by. It deprives 
them of the education they need and deserve to achieve their goals. Student retention and meaningful learning in these cases is, at best, questionable.

Second, Prairie needs to invite students and teachers to join in planning and implementing school changes. It is disheartening that the students and the teachers did not like the new building in spite of the 2.5 million dollar investment by the district. The new school building is appealing with its modern look, spaciousness, cafeteria, and lockers. However, it is revealing that the initiative in the new, modernized building is perceived negatively by its dwellers, including the teachers. In addition, both students and teachers also voiced their resentment about housing all the programs such as Head Start, the middle school, and high school students in one building. The school district's perspective may be that it will be more efficient to administer all of the alternative programs in one building, but it is more like a new warehouse for the teachers and students only in a newer facility. Having all the disenfranchised students from preschool to high school in one building could negatively affect the students' self-esteem and promote a selffulfilling prophecy. Changes in the program without inviting input from the teachers and students causes isolation and alienation. Instead of creating a sense of improved self-worth for students and teachers, they experience oppression and have no sense of ownership in the process or the outcome. This form of hierarchical decision-making is embedded in the educational system in general and continues to reinforce disenfranchisement.

Lastly, more support for teachers at Prairie needs to be provided. Opportunities for professional growth for alternative school teachers need to be offered more systematically and their work need to be highly valued. The teachers' resentment about how they are treated should be acknowledged and addressed. Teaching at an alternative school should not feel like a "deadend" career, and being a second-class teacher who works with "left-overs" from the regular 
school. Unless the school district makes a systemic effort to boost the level of support for the teachers, the negative image about the alternative school will continue to persist.

Without such systemic support, the school will keep maintaining the status quo that is reinforced by dominant groups who are not interested in breaking the cycle of educational inequality (Bourdieu, 1990; Bowles \& Gintis, 1976; Giroux, 1983; Persell, 1977). It will serve merely as a tool to reproduce both the ideologies of the dominant social groups and the hierarchy of the class structure rather than promoting social change, equality, and equity. Hence, not only the students but also the teachers at Prairie Alternative High School do not benefit from the school program and structure. This lack of support perpetuates the struggle for self-emancipation and social change rather than disrupting it.

\section{Conclusion}

In this paper, we revisited the purpose of an alternative school for disenfranchised students by investigating its program and the nature of alternative education from multiple perspectives. Our emerging themes, both the positives and the negatives, indicate the successes and failures of Prairie Alternative High School, now known as the Center for Innovative Studies. We found that the school is successful in providing a caring environment for the students and gaining trust from the students (Noddings, 2005; Rogers \& Freiberg, 1994). However, the school fails to offer an alternative as described by Conley (2002) that encourages the students to achieve their goals by providing the equitable education that they need.

Ultimately, a multidimensional state of disequilibrium permeates the school environment. One side represents a state of caring that exists between the students, teachers, and administrators. Another facet discloses an authoritarian and hegemonic bureaucracy, which prevents the school from providing an education beneficial to the students. This disequilibrium 
makes us wonder who truly benefits from this kind of alternative education. It seems that this alternative education is offered to benefit the population of the regular high school with an assumption that the regular school may work better without the "problem students" in this era of No Child Left Behind. Moreover, housing the Head Start Program, the alternative middle school and high school program in one new building seems to be another way of "warehousing" disenfranchised students. Providing a new, expensive building without substantive and innovative curricular changes and without the voices of students and teachers is benign and purely a superficial and cosmetic act. Consequently, the school vision remains short-sighted, and does not challenge the status quo.

As mentioned in the Introduction, the findings of this study are significant in the following ways: (1) the study points out that a caring and safe learning environment does not necessarily guarantee an equal and equitable education. In other words, an ethical ideal to the experiences of caring must be nurtured through dialogue, practice, and confirmation (Noddings, 2005); (2) the study reveals that it is not only students but also teachers in alternative schools that are marginalized by mainstream education; and (3) the study points out the importance of including the voices of students and teachers in planning and implementing school changes, which requires policy makers to reconsider their hierarchical decision making practice that is pervasive in the educational system in general.

We hope that the significance of our research outcomes will contribute to developing more successful and effective alternative educational programs, thereby making a contribution to enhancing social justice. We urge educators to examine critically and redefine the program of alternative schools. As alternative schools continue to grow in number in the United States, educators must develop alternative programs that disrupt the status quo, which, in turn, leads to 
educational policy for equity and social justice. In order to provide a truly successful alternative education in which inequities and disequilibrium are eliminated, we must first question, an alternative for whom? 


\section{References}

Anfara, V. A., Brown, K. M., \& Mangione, T. (2002). Qualitative analysis on stage: Making the research process more public. Educational Researcher, 31, 28-38.

Anyon, J. (1980). Social Class and the Hidden Curriculum of Work. Journal of Education, 162, $67-92$.

Anyon, J. (1997). Ghetto schooling: A political economy of urban educational reform. New York: Teachers College Press.

Apple, M. (2004). Ideology and Curriculum (3rd ed.). New York: RoutledgeFalmer.

Arnove, R. F., \& Strout, T. (1980). Alternative Schols for Disruptive Youth. Educational Forum, $44,452-471$.

Billings, J. A. (1995). Educational options and alternatives in Washington State. Olympia, Wash.: Office of Superintendent of Public Instruction.

Bourdieu, P. a. J. C. P. (1990). Reproduction in Education, Society, and Culture (second ed.). Newbury Park, CA: Sage.

Bowles, S., \& Gintis, H. (1976). Schooling in Capitalist America: Educational Reform and the Contradictions of Economic Life. New York: Basic Books.

Conley, B. (2002). Alternative Schools: A reference Handbook. Santa Barbara, CA: ABC-CLIO, Inc.

Conrath, J. (2001). A Kappan special section on alternative schools: Changing the odds for young people - Next steps for alternative education. Phi Delta Kappan, 82.

Dance, L. J. (2002). Tough fronts: The impact of street culture on schooling (Critical social thought). New York: NY: Routledge Falmer. 
Denzin, N. K. (1994). The art and politics of interpretation. In N. K. Denzin \& Y. S. Lincoln (Eds.), Handbook of qualitative research (1 ed.). Thousand Oaks, CA: Sage.

Dryfoos, J. G. (1997). Adolescents at risk: Shaping programs to fit the need. Journal of Negro Education, 65(1), 5-18.

Eisner, E. (2001). What does it mean to say a school is doing well? Phi Delta Kappan, 82(5), $367-372$.

Fine, M. (1991). Framing Dropouts: Notes on the Politics of an Urban Public High School. Albany: State University of New York Press.

Fontana, A., \& Frey, J. (2005). The interview: From neutral stance to political involvement. In N. Denzin \& Y. Lincoln (Eds.), Handbook of Qualitative Inquiry (3 ed., pp. 695-728). Thousand Oaks, CA: SAGE Publications.

Freire, P. (1997). Pedagogy of the Oppressed. New York: The Continuum Publishing Company.

Giroux, H. (1983). Theories of Reproduction and Resistance in the New Sociology of Education: A Critical Analysis. Harvard Educational Review, 53(3), 257-293.

Giroux, H. (2001). Theory and Resistance in Education: Towards a Pedagogy for the Opposition. Westport, CT: Bergin \& Garvey.

Giroux, H. (2003). Critical Theory and Educational Practice. In A. Darder, M. Baltodano \& R. Torres (Eds.), The Critical Pedagogy Reader. New York: RoutledgeFalmer.

Glaser, B. G., \& Strauss, A. (1967). The discovery of grounded theory: Strategies for qualitative research. Chicago: Aldine.

Goodman, G. S. (1999). Alternatives in Education: Critical Pedagogy for Disaffected Youth: Peter Lang. 
Greene, M. (2003). In Search of a Critical Pedagogy. In A. Darder, M. Baltodano \& R. Torres (Eds.), The Critical Pedagogy Reader. New York, NY: RoutledgeFalmer.

Kelly, D. M. (1993). Last Chance High: How Girls and Boys Drop In and Out of Alternative Schools. New Haven: Yale University Press.

Kim, J.-H. (2006). For whom the school bell tolls: Conflicting voices inside an alternative high school [Electronic Version]. International Journal of Education and the Arts, 7, 1-21 from Retrieved from http://ijea.asu.edu/v7n6/.

Kvale, S. (1996). InterViews. Thousand Oaks, CA: SAGE Publications.

Land, D., \& Legters, N. (2002). The Extent and Consequences of Risk in U. S. Education. In S. Stringfield \& D. Land (Eds.), Educating At-Risk Students (pp. 1-28). Chicago, Illinois: The University of Chicago Press.

Marsh, C., \& Willis, G. (2003). Curriculum: Alternative Approaches, Ongoing issues (3 ed.). Upper Saddle River, New Jersey: Merrill Prentice Hall.

Mcgee, J. (2001). A Kappan Special Section on Alternative Schools: Reflections of an Alternative School Administrator. Phi Delta Kappan, 82(8), 585-588.

McLaren, P. (2003). Critical Pedagogy: A Look at the Major Concepts. In A. Darder, M. Baltodano \& R. Torres (Eds.), The Critical Pedagogy Reader. New York: RoutledgeFalmer.

National Center for Educational Statistics. (2001). from http://nces.ed.gov/surveys/frss/publications/2002004/6.asp

Noddings, N. (2005). The Challenge to Care in Schools: An Alternative Approach to Education. New York: Teachers College, Columbia University. 
Oakes, J. (1985). Keeping track: How schools structure inequality. New Haven: Yale University Press.

Persell, C. H. (1977). Education and inequality: The roots and results of stratification in America's schools. New York: The Free Press.

Raywid, M. A. (1995). Alternative schools: The state of the art. Educational Leadership, I(September), 26-31.

Stake, R. (2005). Qualitative case studies. In N. Denzin \& Y. Lincoln (Eds.), Handbook of qualitative research (3 ed., pp. 443-466). Thousand Oaks, CA: SAGE Publications.

Valencia, R. R. (1997). Introduction. In R. Valencia (Ed.), The Evolution of Deficit Thinking: Educational Thought and Practice. Washington, D.C.: The Falmer Press.

Valencia, R. R., \& Solorzano, D. G. (1997). Contemporary deficit thinking. In R. Valencia (Ed.), The Evolution of Deficit Thinking. Washington, D.C.: The Falmer Press.

Waxman, H. (1992). Reversing the Cycle of Educational Failure for Students in At-Risk School Environments. In H. Waxman, J. de Felix, J. Anderson \& B. J. P (Eds.), Students at Risk in At-Risk Schools: Improving Environments for Learning. Newbury Park, CA: Corwin Press, Inc.

Young, T. W. (1990). Public alternative schools: Options and choice for today's schools. New York: Teachers College. 


\section{Appendix 1. Interview Questions: Students}

Name:

Ethnicity:
Age:

Gender: Grade:

1. How did you get to this school?
a. How long have you been in this school?
b. What school did you go to before?
c. Why did you choose to come here?

2. What is your school experience like?

3. How do you perceive this school?

4. What are your learning interests/needs?

5. Do you think the school meets/supports your interests/needs? Why or why not?

6. What do you think of the learning materials (curriculum materials)?

7. What are your aspirations after school?

a. Is this school helping you to pursue your aspirations?

b. If yes, how? If no, why not? 


\section{Appendix 2. Interview Questions: Teachers}

Name:

Ethnicity:

Years Teaching:

Grade/s and Subject teaching:

Degree:

Concentration:

1. How did you get to this school?
a. How long have you been in this school?
b. What school did you go to before?
c. Why did you choose to come here?

2. What is your teaching experience like in this school?

3. How do you perceive this school

4. What are your teaching interests/needs?

5. What do you think students' needs/interests are?

6. Do you think the school meets/supports your interests/needs? Why or why not?

7. What do you think of the curriculum materials you use?

8. What kind of support do you receive from the administration?

9. What do you think the community's perception of the school is?

10. How are parents involved? 


\section{Appendix 3. Interview Questions: Administrators}

Name:

Ethnicity:

Years in administration:

Degree:
Age:

Gender:

Years working in this school

1. How did you get to this school?
a. How long have you been in this school?
b. What school did you go to before?
c. Why did you choose to come here?

2. What is your professional experience like in this school?

3. How do you perceive this school?

4. What are your teaching interests/needs?

5. What do you think students' needs/interests are?

6. Do you think the school meets/supports your interests/needs? Why or why not?

7. What kind of support do you receive from the administration?

8. What do you think the community's perception of the school is?

9. How are parents involved?

10. What do you think the community's perception of the school is? 